\title{
EFFECT OF PARTIALLY HYDROLYSED LIPIDS ON INHIBITION OF OXIDATION OF MARINE LIPIDS
}

Santiago P. Aubourg

Instituto de Investigaciones Marinas (CSIC)

c/ E. Cabello, 6

36208-VIGO (Spain)

Fax: + 34-986-292762

E-mail: saubourg@iim.csic.es 


\begin{abstract}
The role of partially hydrolysed glyceride compounds (monoglycerides, MG; diglycerides, DG) on the protective effect of a natural antioxidant (citric acid) in a commercial marine oil (cod liver oil) was investigated during the heat treatment. Lipid oxidation development was analysed by fluorescence and browning detections. An inhibitory effect of the antioxidant action was observed at $50^{\circ} \mathrm{C}$ for all the concentrations tested (MG: 0.1-5.0\%; DG: 0.1-2.0\%) that was faster as the hydrolysed lipid was employed in a higher proportion; no inhibitory action of MG and DG was observed at the same concentrations when lower temperatures $\left(15^{\circ} \mathrm{C}\right.$ and $\left.30^{\circ} \mathrm{C}\right)$ were tested. MG including four different branched fatty acids (lauric, myristic, palmitic and stearic) were compared; the inhibitory effect on the citric acid action was found faster and higher when the fatty acid chain was longer.
\end{abstract}

Running Title: Partially hydrolysed lipids and inhibited oxidation

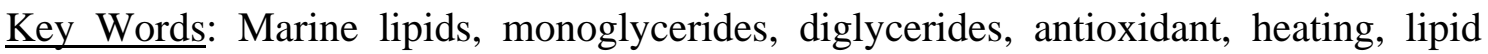
oxidation, chain length 


\section{INTRODUCTION}

Lipid oxidation has been found to strongly influence marine products shelf life $(1,2)$ because of the highly unsaturated lipid composition of marine species (3), the presence of endogenous prooxidant molecules $(4,5)$ and the high temperatures involved in some kinds of fish processing $(6,7)$. Lipid hydrolysis has also been shown to occur during fish processing as a result of enzymatic and non-enzymatic damage pathways (8, 9). In all cases, hydrolysis compounds (free fatty acids, FFA; monoglycerides, MG; diglycerides, DG; and others) themselves have not been shown to lead to nutritional losses, although if present in large quantities they could cause undesirable side reactions and sensory losses $(10,11)$.

Among lipid hydrolysis compounds, most attention has been accorded to the FFA formation. Thus, accumulation of FFA has been related in some extent with lack of acceptability, because FFA are known to cause detrimental effect on $\mathrm{ATP}_{\text {ase }}$ activity, protein solubility and relative viscosity (12), texture deterioration by interacting with proteins (13) and to be interrelated with lipid oxidation development (14). Concerning the remaining hydrolysis products, little research has been carried out to assess their effect on food quality; partially hydrolysed glyceride compounds (MG and DG) have been reported to produce a prooxidant effect in vegetable oils (15).

To avoid lipid damage and to prolong shelf life of food products, great attention is being given to antioxidants employment (16). Recent efforts are now focused on the replacement of synthetic antioxidants by natural ones (17). In the case of marine products, naturally occurring antioxidants have been successfully employed for marine oils (18), minced fish (19) and filleted fish (20). 
In a previous work (21), a natural antioxidant (citric acid) showed a protective effect towards marine lipids during the thermal treatment. The present experiment was designed to assess the effect of partially hydrolysed glyceride compounds (MG and DG) on the inhibition of oxidation caused by citric acid during the heat treatment of a commercial marine oil.

\section{MATERIALS AND METHODS}

\section{Raw material and chemicals}

Cod liver oil (CLO) was obtained from a commercial source (Bama Geve, S. A.; Barcelona, Spain). Before employment, acid value (0.9mg $\mathrm{KOH} / \mathrm{g}$ lipids), peroxide value (1.6meq $\mathrm{O}_{2} / \mathrm{kg}$ lipids) (22) and fatty acid composition (23) were analysed. The following proportions (\%) of fatty acids were obtained: 3.55 (C 14:0), 0.46 (C 15:0),

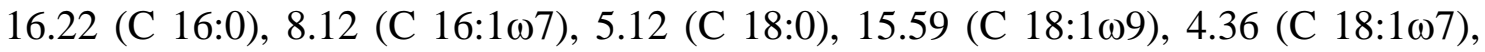

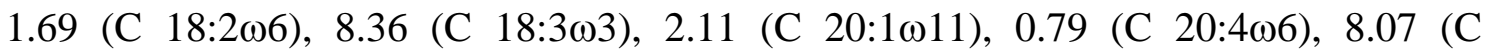

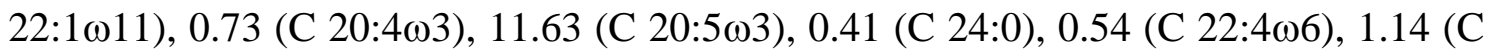
22:5

Chemicals employed (propylamine, citric acid and organic solvents) were reagent grade (E. Merck, Darmstadt, Germany). Partially hydrolysed glyceride compounds (MG and DG) were purchased from Fluka (Chemie AG, Buchs, Switzerland). 


\section{Reaction systems preparation}

CLO reaction mixtures described bellow were incubated in all cases in triplicate in stoppered tubes in the dark at the mentioned temperature without stirring. Blank samples consisted of the individual starting reagents (CLO; propylamine, Pam; citric acid, CA; MG; DG) and mixtures (CLO+Pam, CLO+Pam+CA, MG+Pam and DG+Pam) under the same reaction conditions.

Monopalmitoyl-glycerol and dipalmitoyl-glycerol experiments: Solutions of 1monopalmitoyl-glycerol (16-MG) and 1,2-dipalmitoyl-glycerol (16-DG) (0.125g 16MG or 16-DG /25ml chloroform-aq. 86\% ethanol, 1:1) were prepared. CLO portions (0.5g) were dissolved in $10 \mathrm{ml}$ chloroform and $5 \mathrm{ml}$ of CA solution $(0.125 \mathrm{~g} / 250 \mathrm{ml}$ chloroform-aq. $86 \%$ ethanol, $1: 1)$ were added leading to a $0.50 \%$ CA/CLO ratio (w/w). Then, the 16-MG and 16-DG solutions were added to obtain the following 16-MG/CLO and 16-DG/CLO (w/w) proportions and reaction mixtures: 0.1\% (16-MG $\left.\mathrm{M}_{1}\right), 0.5 \%(16-$ $\left.\mathrm{MG}_{2}\right), 2.0 \%\left(16-\mathrm{MG}_{3}\right)$ and $5.0 \%\left(16-\mathrm{MG}_{4}\right) ; 0.1 \%\left(16-\mathrm{DG}_{1}\right), 0.5 \%\left(16-\mathrm{DG}_{2}\right)$ and $2.0 \%$ (16-DG 3 ). The mixture chloroform-aq. 86\% ethanol (1:1) was employed to complete each reaction system to $20 \mathrm{ml}$ volume. Finally, $10 \mathrm{ml}$ of Pam solution $(0.592 \mathrm{~g} / 200 \mathrm{ml}$ aq. $86 \%$ ethanol) were added. Samples were incubated at $50^{\circ} \mathrm{C}$ and analysed at day $1,3,6$, 10 and 15 ; mixtures consisting of the $2.0 \%$ proportion $\left(16-\mathrm{MG}_{3}\right.$ and $\left.16-\mathrm{DG}_{3}\right)$ were also incubated at $15^{\circ} \mathrm{C}$ and $30^{\circ} \mathrm{C}$.

Different chain length MG experiment: Chloroform-aq. 86\% ethanol (1:1) solutions (3.78 mM) of 1-monolauroyl-glycerol (12-MG), 1-monomyristoyl-glycerol (14-MG), 16-MG and 1-monostearoyl-glycerol (18-MG) were prepared. CLO portions (0.5g) 
were dissolved in $10 \mathrm{ml}$ chloroform and $5 \mathrm{ml}$ of CA solution $(0.125 \mathrm{~g} / 100 \mathrm{ml}$ chloroformaq. $86 \%$ ethanol, $1: 1)$ were added leading to a $1.25 \%$ CA/CLO ratio (w/w). Then, $5 \mathrm{ml}$ of each MG solution were added. Finally, $10 \mathrm{ml}$ of the above mentioned Pam solution were added. Samples were incubated at $50{ }^{\circ} \mathrm{C}$ and analysed at day 1, 3, 6, 10, 15 and 25.

\section{Lipid oxidation assessment}

Fluorescence measurements (Perkin-Elmer LS 3B) were made at 327/415 nm and 393/463 nm excitation/emission maxima $(24,25)$. Relative fluorescences (RF) were calculated as $\mathrm{RF}=\mathrm{F} / \mathrm{F}_{\mathrm{st}}$, where $\mathrm{F}$ is the sample fluorescence at each excitation/emission maximum, and $\mathrm{F}_{\mathrm{st}}$ is the fluorescence intensity of a quinine sulphate solution ( $1 \mu \mathrm{g} / \mathrm{ml}$ in $\left.0.05 \mathrm{M} \mathrm{H}_{2} \mathrm{SO}_{4}\right)$ at the corresponding wavelength. The fluorescence ratio $(\delta \mathrm{F})$ value was calculated as: $\delta \mathrm{F}=\mathrm{RF}_{393 / 463 \mathrm{~nm}} / \mathrm{RF}_{327 / 415 \mathrm{~nm}}$.

Brown coloration was measured at $420 \mathrm{~nm}$ (26). Results were calculated using the following formula: Browning value $(\mathrm{BV})=\mathrm{A} \times \mathrm{v} / \mathrm{w}$, where $\mathrm{A}$ is the absorbance reading at $420 \mathrm{~nm}$, v denotes the volume (ml) of the sample and $\mathrm{w}$ is the mass ( $\mathrm{g}$ ) of the sample.

\section{Statistical analysis}

Fluorescence ratio $(\delta \mathrm{F})$ and browning $(\mathrm{BV})$ values were subjected to the ANOVA one-way method $(\mathrm{p}<0.05)$; comparison of means after the ANOVA test were performed using a least-squares difference (LSD) method (27).

\section{RESULTS}


Lipid oxidation compounds (e.g., peroxides and carbonyls) produced from CLO during the present experiment interacted with Pam to produce Schiff bases and other interaction compounds that were assessed by fluorescence and browning detections (25, 28, 29). In the absence of CLO+Pam, no changes in both assessments were observed along the reaction time; this was the case of the individual reagent blanks (CLO, Pam, CA, MG and DG) and also the mixtures Pam+MG and Pam+DG, including different reagent ratios (data not shown). Accordingly, the effect of MG and DG on the inhibition of lipid oxidation caused by CA was evaluated by comparison with the CLO+Pam reaction system (oil blank, OB) and with the CLO+Pam+CA reaction system (citric acid blank, CAB).

\section{Effect of MG and DG at $50^{\circ} \mathrm{C}$}

In the case of MG, the fluorescence assessment (Table 1) showed an inhibitory effect on CA action at day 6 of reaction in the two higher concentrations (16- $\mathrm{MG}_{3}$ and $16-\mathrm{MG}_{4}$ ); this effect increased along the whole reaction period and finally (day 15), the protective effect of CA was inhibited in all the concentrations tested (0.1-5.0\%). The results observed from the browning detection (Figure 1) led to similar conclusions as the results from fluorescence detection. Again, no significant $(\mathrm{p}<0.05)$ differences in oxidation development could be obtained at the end of the experiment among the different MG concentrations that were evaluated.

Reaction mixture consisting of the highest DG content $\left(16-\mathrm{DG}_{3}\right)$ showed an inhibitory effect on CA action at day 3 (Table 2). At the end of the reaction time (day 15), all the DG concentrations evaluated (0.1-2.0\%) did not show significant differences as compared with the non-protected mixture (OB sample) but were higher than the protected system (CAB sample). The browning detection also showed the inhibitory 
effect of DG on the protection caused by CA (Figure 2), although again no significant $(p<0.05)$ differences in oxidation development could be obtained at the end time among the different DG concentrations tested.

\section{Effect of MG and DG at lower temperatures}

The effect of MG and DG on the inhibition of oxidation of CLO by CA was also studied at lower temperatures $\left(15^{\circ} \mathrm{C}\right.$ and $\left.30^{\circ} \mathrm{C}\right)$. For both hydrolysed lipid classes, the fluorescence assessment at $15^{\circ} \mathrm{C}$ (Table 3) and $30^{\circ} \mathrm{C}$ (Table 4) did not show an inhibitory effect on the CA protective action. During the whole experiment no significant differences among the CAB system and samples including MG or DG could be obtained. In most cases, the OB system (absence of CA) showed a higher oxidation development than the remaining samples.

Browning values gave rise to similar conclusions. A higher oxidation development was observed for the OB sample than for the remaining ones $(p<0.05)$. The presence of $\mathrm{MG}$ and DG at both temperatures $\left(15^{\circ} \mathrm{C}\right.$, Figure $3 ; 30^{\circ} \mathrm{C}$, Figure 4$)$ did not provide significant $(\mathrm{p}<0.05)$ increases in oxidation damage when compared to the CAB mixture. Accordingly, the CA effect was not inhibited.

\section{Effect of the MG chain length}

The effect of the chain length of the fatty acid included in the MG molecule on the CA inhibited oxidation was studied. Four different MG were considered (Materials and Methods section). According to the fluorescence assessment (Table 5), at day 6 of reaction 16-MG and 18-MG showed an inhibitory effect on the protective effect of the antioxidant. At day 15, this effect was also observed for 14-MG sample. At the end of the reaction time (25 days), all MG showed a higher oxidation development compared 
to the protected mixture (CAB sample). In addition, 14-MG, 16-MG and 18-MG did not show significant differences as compared with the non-protected sample (OB mixture). Comparison among MG, only showed a higher value for 18-MG than for 12-MG at the end of the experiment.

According to the browning detection (Figure 5), 14-MG, 16-MG and 18-MG showed an inhibitory effect on the CA action at day $10(\mathrm{p}<0.05)$. At the end of the experiment, this effect could also be observed for 12-MG, and none of the MG samples showed significant $(\mathrm{p}<0.05)$ differences as compared with the non-protected mixture (OB system). Comparison among the different MG showed a gradual increase in the browning value as the chain length increased.

\section{DISCUSSION}

MG and DG caused an inhibitory effect on the antioxidant action of CA when a commercial marine oil was tested in a heated $\left(50^{\circ} \mathrm{C}\right)$ model system. This effect was observed at different concentrations (MG: 0.1-5.0\%; DG: 0.1-2.0\%) and was faster when a higher concentration of both hydrolysed glyceride compounds was employed. When lower temperatures $\left(15^{\circ} \mathrm{C}\right.$ and $\left.30^{\circ} \mathrm{C}\right)$ were studied this inhibitory effect on CA could not be observed under the same reaction conditions.

Results agree with previous research focused on the role of fatty alcohols in inhibited oxidation of vegetable oils when synthetic phenolic antioxidants (pmethoxyphenol and hydroquinone) (30, 31) were studied. In this case, fatty alcohols, including MG, were shown to inhibit the antioxidant effect as a result of blocking the phenolic antioxidant through the formation of a hydrogen bond-based complex. 
According to the present results at $15^{\circ} \mathrm{C}$ and $30^{\circ} \mathrm{C}$, no changes in the oxidation stability and the oxidation rate of the inhibited lipid system were found at room temperature when fatty alcohols (1-tetradecanol and 1-octadecanol) were present (31). Since lipid oxidation is not favoured from a kinetic point of view, at lower temperatures activation energies are more difficult to be attained, lipid oxidation develops slowly, and it could be argued that the presence of MG or DG would not produce a significant effect in systems checked in the present experiment.

Present results on comparison of different kinds of MG showed a faster and higher inhibitory action on the CA effect when MG including longer chain lengths were considered. This difference may be explained on the basis that a longer chain length in the branched fatty acid would mean a higher positive inductive effect of the hydrocarbon chain on the hydroxilic groups (32), so that the nucleophilicity of the hydroxy oxygen would be enhanced and participation in the hydrogen bond interaction with the lipid oxidation inhibitor would be increased. This positive inductive effect of the hydrocarbon chain length had also been observed when comparing the ability of different kinds of aliphatic amines (nucleophilic behaviour) in producing fluorescent compounds (33).

Marine products have been reported to include a great diversity of endogenous antioxidants $(35,36)$ and to be treated with a wide number of exogenous natural antioxidants $(16,17)$. Since lipid hydrolysis is widely produced as a result of heat treatment (cooking, sterilisation, smoking, drying) of marine products $(6,9,34)$, a great attention should be given to minimise the partially hydrolysed lipids formation to avoid inhibition of endogenous and exogenous antioxidants action, that could lead to lipid oxidation development of the highly unsaturated fatty acids $(1,3)$ of marine products. 


\section{ACKNOWLEDGEMENTS}

The author acknowledges Mr. Marcos Trigo and Mrs. Janet Ares for technical assistance and the Comisión Interministerial de Ciencia y Tecnología (CICyT; Spain) for financial support through the research project ALI 99-0869 (2000-2002). 


\section{REFERENCES}

1. Pigott G, Tucker B (1987) Food Rev Intern 3:105-138

2. Hsieh R, Kinsella J (1989) Adv Food Res Nutr Res 33:233-341

3. Ackman R (1989) Fatty acids. In: Ackman R (ed) Marine biogenic lipids, fats and oils. CRC Press, Boca Raton, Florida (USA), Vol 1, pp 103-137

4. German B, Zhang H, Berger R (1992) Role of lipoxygenases in lipid oxidation in foods. In: St Angelo A (ed) Lipid oxidation in food. American Chemical Society, Washington, DC (USA), pp 74-92

5. Harris P, Tall J (1994) Rancidity in fish. In: Allen J, Hamilton R (eds) Rancidity in foods. Chapman and Hall, London (UK), pp 256-272

6. Bligh E, Shaw S, Woyewoda A (1988) The effect of drying and smoking on lipids of fish. In: Burt J (ed) Fish smoking and drying. Elsevier App Sci, London (UK) and New York (USA), pp 41-52

7. Horner W (1997) Canning fish and fish products. In: Hall G (ed) Fish processing technology, $2^{\text {nd }}$ edition. Blackie Academic and Professional, Chapman and Hall, London (UK), pp 119-159

8. Shewfelt R (1981) J Food Biochem 5:79-100

9. Gallardo J, Aubourg S, Pérez-Martín R (1989) J Agric Food Chem 37:1060-1064

10. de Koning A, Milkovitch S, Fick M, Wessels J (1986) Fette Seifen Anstrichm 88:404-406

11. Pokorný J (1990) Nahrung 34:887-897

12. Careche M, Tejada M (1994) J Sci Food Agric 64:501-507

13. Mackie I (1993) Foods Rev Int 9:575-610

14. Han T, Liston J (1988) J Food Sci 53:1917-1918 
15. Mistry B, Min D (1988) J Food Sci 53:1896-1897

16. Decker E (1998) Trends Food Sci Technol 9:241-248

17. Frankel E (1995) Lipid Technol (July) 77-80

18. Thorrisson S, Gunstone F, Hardy R (1992) J Am Oil Chem Soc 69:806-809

19. Boyd L, Green D, Giesbrecht F, King M (1993) J Sci Food Agric 61:87-93

20. Vareltzis K, Koufidis D, Graviilidou E, Papavergou E, Vasiliadou S (1997) Z Lebensm Unters Forsch 205:93-96

21. Aubourg S (2000) Eur Food Res Technol In press

22. Williams K (1950) Oils, fats and fatty foods. Their practical examination, $3^{\text {rd }}$ edn. J. \& A. Churchill Ltd, London (UK), pp 53-54, 107-108

23. Lepage G, Roy C (1986) J Lipid Res 27:114-120

24. Aubourg S, Medina I, Pérez-Martín R (1995) Z Lebensm Unters Forsch 200:252255

25. Aubourg S (1999) J Am Oil Chem Soc 76:409-419

26. Labuza T, Massaro S (1990) J Food Sci 55:821-826

27. Statsoft (1994) Statistica for Macintosh. Statsoft and its licensors. Tulsa, Oklahoma (USA)

28. Cheftel J, Cheftel H (1976) Introducción a la Bioquímica y Tecnología de Alimentos. Acribia, Zaragoza (Spain), pp 291-308

29. Leake L, Karel M (1985) J Food Biochem 9:117-136

30. Kortenska V, Yanishlieva N, Roginskii V (1991) J Am Oil Chem Soc 68:888-890

31. Yanishlieva N, Kortenska V (1993) Fat Sci Technol 95:35-40

32. Fieser L, Fieser M (1966) Química Orgánica Superior. Ediciones Grijalbo, S A, Barcelona (Spain), p 481

33. Aubourg S, Gallardo J (1997) Int J Food Sci Technol 32:153-158 
34. Medina I, Aubourg S, Gallardo J (2000) Eur Food Res Technol 210:353-358

35. Petillo D, Hultin H, Krzynowek J, Autio W (1998) J Agric Food Chem 46:41284137

36. Undeland I, Ekstrand B, Lingnert H (1998) J Am Oil Chem Soc 75:581-590 


\section{FIGURE LEGENDS}

Figure 1: Browning values (BV)* obtained by oxidation of cod liver oil (CLO) at $50^{\circ} \mathrm{C}$ in the presence propylamine, citric acid (0.50\%) and monopalmitoyl-glycerol (16MG)**

* Mean values of three independent determinations. Initial BV of CLO was: $2.52 \pm$ 0.069 .

** Four different 16-MG/CLO ratios (w/w) were evaluated: $16-\mathrm{MG}_{1}(0.1 \%), 16-\mathrm{MG}_{2}$ (0.5\%), 16- $\mathrm{MG}_{3}(2.0 \%)$ and 16- $\mathrm{MG}_{4}(5.0 \%)$. Other abbreviations: OB (oil blank) and CAB (citric acid blank).

Figure 2: Browning values (BV)* obtained by oxidation of cod liver oil (CLO) at $50^{\circ} \mathrm{C}$ in the presence propylamine, citric acid (0.50\%) and dipalmitoyl-glycerol (16-DG)**

* Mean values of three independent determinations. Initial BV of CLO was: $2.52 \pm$ 0.069 .

** Three different 16-DG/CLO ratios (w/w) were evaluated: $16-\mathrm{DG}_{1}(0.1 \%), 16-\mathrm{DG}_{2}$ (0.5\%) and $16-\mathrm{DG}_{3}(2.0 \%)$. Other abbreviations as specified in Figure 1. 
Figure 3: Browning values (BV)* obtained by oxidation of cod liver oil (CLO) at $15^{\circ} \mathrm{C}$ in the presence propylamine, citric acid (0.50\%) and monopalmitoyl-glycerol (16-MG) or dipalmitoyl-glycerol (16-DG)**

* Mean values of three independent determinations. Initial BV value of CLO was: 2.52 \pm 0.069 .

** The 2.0\% concentration samples (w/w; 16- $\mathrm{MG}_{3}$ and $16-\mathrm{DG}_{3}$, Figures 1 and 2, respectively) were evaluated. Other abbreviations as specified in Figure 1.

Figure 4: Browning values (BV)* obtained by oxidation of cod liver oil (CLO) at $30^{\circ} \mathrm{C}$ in the presence propylamine, citric acid (0.50\%) and monopalmitoyl-glycerol (16-MG) or dipalmitoyl-glycerol (16-DG)**

* Mean values of three independent determinations. Initial BV value of CLO was: 2.52 \pm 0.069 .

** The $2.0 \%$ concentration samples $\left(\mathrm{w} / \mathrm{w} ; 16-\mathrm{MG}_{3}\right.$ and $16-\mathrm{DG}_{3}$, Figures 1 and 2, respectively) were evaluated. Other abbreviations as specified in Figure 1. 
Figure 5: Browning values (BV)* obtained by oxidation of cod liver oil (CLO) at $50^{\circ} \mathrm{C}$ in the presence propylamine, citric acid $(0.50 \%)$ and monoglycerides with different chain lengths**

* Mean values of three independent determinations. Initial BV value of CLO was: 2.32 $\pm 0.181$

** Four different MG were checked: monolauroyl-glycerol (12-MG), monomiristoylglycerol (14-MG), monopalmitoyl-glycerol (16-MG) and monostearoyl-glycerol (18-MG); the same molar concentration (3.78 mM) was employed in all of them. Other abbreviations as specified in Figure 1. 


\section{TABLE 1}

Fluorescence ratio $(\delta \mathrm{F})$ values* obtained by oxidation of cod liver oil (CLO) at $50^{\circ} \mathrm{C}$ in the presence of propylamine, citric acid (0.50\%) and monopalmitoyl-glycerol (16-

$$
\mathrm{MG})^{* *}
$$

REACTION TIME (days)

\begin{tabular}{|c|c|c|c|c|c|}
\hline $\begin{array}{c}\text { Reaction } \\
\text { Mixture }\end{array}$ & 1 & 3 & 6 & 10 & 15 \\
\hline OB & $9.86 \mathrm{~b}$ & $\begin{array}{c}15.45 \mathrm{~b} \\
(0.456)\end{array}$ & $\begin{array}{c}24.57 \mathrm{c} \\
(0.762)\end{array}$ & $\begin{array}{c}34.20 \mathrm{c} \\
(0.977)\end{array}$ & $\begin{array}{c}43.47 \mathrm{~b} \\
(1.244)\end{array}$ \\
\hline $\mathrm{CAB}$ & $7.17 \mathrm{a}$ & $11.11 \mathrm{a}$ & $18.45 \mathrm{a}$ & $25.92 \mathrm{a}$ & $34.02 \mathrm{a}$ \\
& $(0.276)$ & $(1.094)$ & $(2.330)$ & $(0.042)$ & $(0.375)$ \\
\hline $16-\mathrm{MG}_{1}$ & $7.66 \mathrm{a}$ & $12.07 \mathrm{a}$ & $20.22 \mathrm{ab}$ & $30.61 \mathrm{~b}$ & $40.46 \mathrm{~b}$ \\
& $(0.226)$ & $(0.222)$ & $(0.940)$ & $(0.448)$ & $(0.705)$ \\
\hline $16-\mathrm{MG}_{2}$ & $7.54 \mathrm{a}$ & $11.59 \mathrm{a}$ & $20.11 \mathrm{ab}$ & $30.10 \mathrm{~b}$ & $39.96 \mathrm{~b}$ \\
& $(0.578)$ & $(0.723)$ & $(1.581)$ & $(0.527)$ & $(1.720)$ \\
\hline $16-\mathrm{MG}_{3}$ & $7.37 \mathrm{a}$ & $11.71 \mathrm{a}$ & $20.98 \mathrm{~b}$ & $31.22 \mathrm{~b}$ & $40.63 \mathrm{~b}$ \\
& $(0.407)$ & $(0.440)$ & $(1.096)$ & $(1.877)$ & $(2.250)$ \\
\hline $16-\mathrm{MG}_{4}$ & $7.83 \mathrm{a}$ & $12.02 \mathrm{a}$ & $21.05 \mathrm{~b}$ & $33.24 \mathrm{c}$ & $40.52 \mathrm{~b}$ \\
& $(0.353)$ & $(1.074)$ & $(1.108)$ & $(0.733)$ & $(3.461)$ \\
\hline
\end{tabular}

* Mean values of three independent determinations. Values in the same column followed by different letters are significantly different $(\mathrm{p}<0.05)$. Standard deviations are indicated in parentheses. Initial $\delta \mathrm{F}$ value of CLO was $3.03 \pm$ 0.259 .

** Four different 16-MG/CLO ratios (w/w) were evaluated: $16-\mathrm{MG}_{1}(0.1 \%), 16-\mathrm{MG}_{2}$ (0.5\%), $16-\mathrm{MG}_{3}(2.0 \%)$ and $16-\mathrm{MG}_{4}$ (5.0\%). Other abbreviations: OB (oil blank) and CAB (citric acid blank). 
TABLE 2

Fluorescence ratio $(\delta \mathrm{F})$ values* obtained by oxidation of cod liver oil (CLO) at $50^{\circ} \mathrm{C}$ in the presence of propylamine, citric acid $(0.50 \%)$ and dipalmitoyl-glycerol (16-DG)**

REACTION TIME (days)

\begin{tabular}{|c|c|c|c|c|c|}
\hline $\begin{array}{c}\text { Reaction } \\
\text { Mixture }\end{array}$ & 1 & 3 & 6 & 10 & 15 \\
\hline OB & $10.03 \mathrm{~b}$ & $\begin{array}{c}15.77 \mathrm{c} \\
(1.900)\end{array}$ & $\begin{array}{c}25.04 \mathrm{c} \\
(0.856)\end{array}$ & $\begin{array}{c}35.02 \mathrm{c} \\
(1.060)\end{array}$ & $\begin{array}{c}45.27 \mathrm{~b} \\
(2.643)\end{array}$ \\
\hline $\mathrm{CAB}$ & $6.59 \mathrm{a}$ & $12.48 \mathrm{a}$ & $22.08 \mathrm{a}$ & $29.56 \mathrm{a}$ & $37.48 \mathrm{a}$ \\
& $(0.288)$ & $(0.428)$ & $(0.773)$ & $(1.242)$ & $(2.205)$ \\
\hline $16-\mathrm{DG}_{1}$ & $6.95 \mathrm{a}$ & $13.16 \mathrm{ab}$ & $21.97 \mathrm{a}$ & $32.03 \mathrm{ab}$ & $43.33 \mathrm{~b}$ \\
& $(0.844)$ & $(1.589)$ & $(0.936)$ & $(1.449)$ & $(3.916)$ \\
\hline $16-\mathrm{DG}_{2}$ & $7.35 \mathrm{a}$ & $13.72 \mathrm{ab}$ & $23.14 \mathrm{ab}$ & $31.80 \mathrm{ab}$ & $43.61 \mathrm{~b}$ \\
& $(0.817)$ & $(1.436)$ & $(0.819)$ & $(2.108)$ & $(2.999)$ \\
\hline $16-\mathrm{DG}_{3}$ & $7.44 \mathrm{a}$ & $14.07 \mathrm{~b}$ & $24.53 \mathrm{bc}$ & $33.42 \mathrm{bc}$ & $44.24 \mathrm{~b}$ \\
& $(1.291)$ & $(1.083)$ & $(1.028)$ & $(2.757)$ & $(2.329)$ \\
\hline
\end{tabular}

* Mean values of three independent determinations. Values in the same column followed by different letters are significantly different $(p<0.05)$. Standard deviations are indicated in parentheses. Initial $\delta F$ value of CLO was $3.03 \pm$ 0.259 .

** Three different 16-DG/CLO ratios (w/w) were evaluated: $16-\mathrm{DG}_{1}(0.1 \%), 16-\mathrm{DG}_{2}$ $(0.5 \%)$ and $16-\mathrm{DG}_{3}(2.0 \%)$. Other abbreviations as specified in Table 1. 
TABLE 3

Fluorescence ratio $(\delta \mathrm{F})$ values* obtained by oxidation of cod liver oil (CLO) at $15^{\circ} \mathrm{C}$ in the presence of propylamine, citric acid $(0.50 \%)$ and monopalmitoyl-glycerol (16-MG) or dipalmitoyl-glycerol (16-DG)**

\section{REACTION MIXTURE}

\begin{tabular}{|c|c|c|c|c|}
\hline $\begin{array}{c}\text { Reaction Time } \\
\text { (days) }\end{array}$ & OB & CAB & $16-\mathrm{MG}_{3}$ & $16-\mathrm{DG}_{3}$ \\
\hline 1 & $3.15 \mathrm{a}$ & $2.92 \mathrm{a}$ & $3.22 \mathrm{a}$ & $3.16 \mathrm{a}$ \\
$(0.379)$ & $(0.096)$ & $(0.324)$ & $(0.161)$ \\
\hline 3 & $3.80 \mathrm{a}$ & $3.46 \mathrm{a}$ & $3.78 \mathrm{a}$ & $3.83 \mathrm{a}$ \\
& $(0.065)$ & $(0.126)$ & $(0.254)$ & $(0.082)$ \\
\hline 6 & $4.10 \mathrm{~b}$ & $3.54 \mathrm{a}$ & $3.85 \mathrm{ab}$ & $3.71 \mathrm{ab}$ \\
& $(0.397)$ & $(0.097)$ & $(0.149)$ & $(0.091$ \\
\hline 10 & $5.38 \mathrm{~b}$ & $4.28 \mathrm{a}$ & $4.47 \mathrm{a}$ & $4.23 \mathrm{a}$ \\
& $(0.468)$ & $(0.047)$ & $(0.115)$ & $(0.014)$ \\
\hline 15 & $6.95 \mathrm{~b}$ & $5.63 \mathrm{a}$ & $5.73 \mathrm{a}$ & $5.39 \mathrm{a}$ \\
& $(0.198)$ & $(0.846)$ & $(0.330)$ & $(0.440)$ \\
\hline
\end{tabular}

* Mean values of three independent determinations. Values in the same row followed by different letters are significantly different $(\mathrm{p}<0.05)$. Standard deviations are indicated in parentheses. Initial $\delta F$ value of CLO was $3.03 \pm 0.259$.

** The $2.0 \%$ concentration samples (w/w; 16- $\mathrm{MG}_{3}$ and $16-\mathrm{DG}_{3}$, Tables 1 and 2, respectively) were evaluated. Other abbreviations as specified in Table 1. 
TABLE 4

Fluorescence ratio $(\delta \mathrm{F})$ values* obtained by oxidation of cod liver oil $(\mathrm{CLO})$ at $30^{\circ} \mathrm{C}$ in the presence of propylamine, citric acid (0.50\%) and monopalmitoyl-glycerol (16-MG) or dipalmitoyl-glycerol (16-DG)**

REACTION MIXTURE

\begin{tabular}{|c|c|c|c|c|}
\hline $\begin{array}{c}\text { Reaction Time } \\
\text { (days) }\end{array}$ & OB & CAB & $16-\mathrm{MG}_{3}$ & $16-\mathrm{DG}_{3}$ \\
\hline 1 & $6.34 \mathrm{~b}$ & $5.46 \mathrm{a}$ & $5.63 \mathrm{a}$ & $5.40 \mathrm{a}$ \\
& $(324)$ & $(0.183)$ & $(0.346)$ & $(0.289)$ \\
\hline 3 & $10.99 \mathrm{~b}$ & $8.19 \mathrm{a}$ & $8.54 \mathrm{a}$ & $8.14 \mathrm{a}$ \\
& $(709)$ & $(0.036)$ & $(0.468)$ & $(0.044)$ \\
\hline 6 & $16.87 \mathrm{~b}$ & $11.42 \mathrm{a}$ & $11.93 \mathrm{a}$ & $11.60 \mathrm{a}$ \\
& $(1.381)$ & $(0.348)$ & $(1.030)$ & $(0.557)$ \\
\hline 10 & $24.06 \mathrm{~b}$ & $16.42 \mathrm{a}$ & $16.78 \mathrm{ab}$ & $15.90 \mathrm{a}$ \\
& $(0.898$ & $(0.283)$ & $(0.327)$ & $(0.246)$ \\
\hline 15 & $28.90 \mathrm{~b}$ & $20.38 \mathrm{a}$ & $21.66 \mathrm{ab}$ & $20.56 \mathrm{a}$ \\
& $(0.240)$ & $(0.813)$ & $(0.969)$ & $(0.621)$ \\
\hline
\end{tabular}

* Mean values of three independent determinations. Values in the same row followed by different letters are significantly different $(\mathrm{p}<0.05)$. Standard deviations are indicated in parentheses. Initial $\delta \mathrm{F}$ value of CLO was $3.03 \pm 0.259$.

** The $2.0 \%$ concentration samples (w/w; 16- $\mathrm{MG}_{3}$ and $16-\mathrm{DG}_{3}$, Tables 1 and 2, respectively) were evaluated. Other abbreviations as specified in Table 1. 
Fluorescence ratio $(\delta \mathrm{F})$ values* obtained by oxidation of cod liver oil $(\mathrm{CLO})$ at $50^{\circ} \mathrm{C}$ in the presence of propylamine, citric acid (0.50\%) and monoglycerides with different chain lengths**

REACTION TIME (days)

\begin{tabular}{|c|c|c|c|c|c|c|}
\hline $\begin{array}{l}\text { Reaction } \\
\text { Mixture }\end{array}$ & 1 & 3 & 6 & 10 & 15 & 25 \\
\hline OB & $\begin{array}{l}9.20 \mathrm{~b} \\
(0.495)\end{array}$ & $\begin{array}{c}12.47 \mathrm{~b} \\
(610)\end{array}$ & $\begin{array}{l}18.90 \text { с } \\
(0.979)\end{array}$ & $\begin{array}{l}22.92 \text { c } \\
(1.362)\end{array}$ & $\begin{array}{l}28.16 \text { c } \\
(0.301)\end{array}$ & $\begin{array}{l}51.15 \text { c } \\
(5.227)\end{array}$ \\
\hline CAB & $\begin{array}{l}5.25 \mathrm{a} \\
(0.055)\end{array}$ & $\begin{array}{l}7.91 \text { a } \\
(0.214)\end{array}$ & $\begin{array}{c}14.88 \mathrm{a} \\
(0.201)\end{array}$ & $\begin{array}{l}19.49 \mathrm{a} \\
(1.237)\end{array}$ & $\begin{array}{l}24.11 \mathrm{a} \\
(1.030)\end{array}$ & $\begin{array}{l}40.38 \mathrm{a} \\
(0.798)\end{array}$ \\
\hline 12-MG & $\begin{array}{l}5.43 \mathrm{a} \\
(0.261)\end{array}$ & $\begin{array}{l}8.20 \mathrm{a} \\
(0.182)\end{array}$ & $\begin{array}{c}15.49 \mathrm{ab} \\
(0.791)\end{array}$ & $\begin{array}{c}20.21 \mathrm{ab} \\
(1.525)\end{array}$ & $\begin{array}{c}25.09 \mathrm{ab} \\
(1.361)\end{array}$ & $\begin{array}{c}46.32 \mathrm{~b} \\
(1.065)\end{array}$ \\
\hline 14-MG & $\begin{array}{l}5.68 \mathrm{a} \\
(0.378)\end{array}$ & $\begin{array}{l}8.52 \mathrm{a} \\
(0.534)\end{array}$ & $\begin{array}{c}16.05 \mathrm{ab} \\
(0.308)\end{array}$ & $\begin{array}{c}21.34 \mathrm{abc} \\
(1.148)\end{array}$ & $\begin{array}{c}26.91 \text { bc } \\
(0.801)\end{array}$ & $\begin{array}{c}50.39 \text { bc } \\
(2.609)\end{array}$ \\
\hline 16-MG & $\begin{array}{l}5.61 \text { a } \\
(0.115)\end{array}$ & $\begin{array}{c}8.38 \mathrm{a} \\
(0.146)\end{array}$ & $\begin{array}{l}16.60 \mathrm{~b} \\
(0.697)\end{array}$ & $\begin{array}{c}22.18 \text { bc } \\
(1.296)\end{array}$ & $\begin{array}{c}27.84 \text { bc } \\
(0.960)\end{array}$ & $\begin{array}{c}50.63 \text { bc } \\
(1.334)\end{array}$ \\
\hline 18-MG & $\begin{array}{l}5.74 \text { a } \\
(0.216)\end{array}$ & $\begin{array}{l}8.49 \mathrm{a} \\
(0.336)\end{array}$ & $\begin{array}{l}16.42 \mathrm{~b} \\
(1.440)\end{array}$ & $\begin{array}{c}22.34 \text { bc } \\
(2.010)\end{array}$ & $\begin{array}{c}28.82 \text { bc } \\
(2.400)\end{array}$ & $\begin{array}{l}52.68 \mathrm{c} \\
(1.940)\end{array}$ \\
\hline
\end{tabular}

* Mean values of three independent determinations. Values in the same column followed by different letters are significantly different $(p<0.05)$. Standard deviations are indicated in parentheses. Initial $\delta \mathrm{F}$ value of CLO was $2.76 \pm$ 0.127 .

** Four different MG were evaluated: monolauroyl-glycerol (12-MG), monomiristoylglycerol (14-MG), monopalmitoyl-glycerol (16-MG) and monostearoyl-glycerol (18-MG); the same molar concentration $(3.78 \mathrm{mM})$ was employed for all of them. Other abbreviations as specified in Table 1. 
